\title{
Indirect Factors Affecting Personal Solvency: Empirical Analysis Of Lithuanian Consumer Credit Market
}

\author{
Daiva Jureviciene, Prof., PhD \\ Kamile Taujanskaite, PhD student \\ Vilnius Gediminas Technical University, Lithuania \\ Vytaute Sukacevskyte, MA \\ Independent researcher, Lithuania
}

doi: 10.19044/esj.2016.v12n1p157 URL:http://dx.doi.org/10.19044/esj.2016.v12n1p157

\begin{abstract}
The aim of this article is to analyze the interrelationship between solvencies of consumer credits customers and indirect factors such as borrowing motivation as well as demographical and socioeconomic factors characterizing the borrowers' personality. The results of this research were obtained using statistical software SPSS. Systemic scientific literature analysis, correlation analysis of randomly selected records from consumer credit contracts, Student t-test criteria application for testing hypothesis, analysis of Levine's and Pearson's correlation criteria are used in the article. In addition, previously carried out expert evaluation research results were compared with actual consumer credit contracts data. The novelty of this research is classification of factors influencing personal solvency into direct and indirect. The influence of indirect factors (demographic, socioeconomic and borrowing motives) has been investigated in risky consumer credit market of Lithuania. The results show that the most influencing indirect factor is the purpose of consumer credit.
\end{abstract}

Keywords: Solvency, financial vulnerability, financial liabilities repayment, consumer credit, indirect factors of insolvency

\section{Introduction}

During the last two decades, loans issued to insolvent persons have become a major problem in a number of countries (Baek, Hong, 2004; Keese, 2009; Anderloni, Vandone, 2010; Christelis et. al., 2010; International Monetary Fund, 2013). Researchers have started investigating the causes of insolvency (Lusardi, 2006; Jappelli et al., 2008; Meniago et al., 2013; Kamleitner, Kirchler, 2007; Pahl, 2008). This problem exists in 
Lithuanian financial system as well: the level of insolvent credits was $2 \%$ in 2007, while it has risen to $20 \%$ in 2010. In addition, although the level of insolvent credits dropped to $10 \%$ in 2015, the percentage still remains high (Bank of Lithuania, 2015).

Various scientific investigations have been carried out and revealed the correlation between insolvency and a variety of factors influencing it, e.g., altering macroeconomic environment, interest rate fluctuations, family life cycle changes, financial resources management skills, etc. (Baek, Hong, 2004; Walters, Smith 2010). Some of these factors have a clearly expressed, quantitative (monetary) effect on the flow of households' financial resources, consequently their impact on a person's solvency can be easily forecasted. Thus, these factors have been thoroughly researched. Another group of factors are demographical, socioeconomic, cultural as well as those related to financial literacy, etc., which affect person's solvency indirectly. Their influence on solvency is a subject to sociocultural environment in the society, traditions and other circumstances, which are difficult to define quantifiable. According to Anderloni et al. (2012) the influence of the latter factors should be researched "...in different countries in order to exploit cross-country differences...”.

The impact of indirect factors on personal solvency has not been researched in Lithuania yet. The objective of this article is to investigate the correlation between consumer credit customers' solvency and indirect factors (such as borrowing motivation as well as demographical and socioeconomic factors characterizing the borrowers' personality). Unlike most other studies, which usually analyse generalized statistical data or household survey data, this research is based exclusively on analysis of credit contracts information available from the consumer credit institution in Lithuania.

The results of this research were obtained using statistical software SPSS. Methods used in this research contain: (1) Systemic scientific literature analysis; (2) Empirical quantitative research: correlation analysis of randomly selected records from consumer credit contracts, received from selected consumer credit institution. Application of Student t-test criteria for testing hypothesis; analysis of Levine's criteria, analysis of Pearson's correlation criteria; (3) Comparison analysis: previously carried out expert evaluation research results were compared with actual consumer credit contracts data. The novelty of this work is threefold: (1) To our knowledge, no previous studies have proposed a classification of factors influencing personal solvency into direct and indirect based on their relationship with the flow of financial resources. The insolvency topic is itself significant and can be particularly interesting both for scientists and practitioners when investigating origination of risky loans. (2) The influence of demographic, socioeconomic factors and borrowing motives have been investigated on the 
extent of risky credits in Lithuanian consumer credit market based on the analysis of consumer credits segment contracts. (3) The performed empirical analysis focuses specifically on Lithuanian consumer credit market and provides the possibility to compare the results with other segments of the credit market or other countries in the future.

The first part of this article covers theoretical analysis of insolvency reasons. The second part consists of Lithuanian consumer credit market research determining the influence of indirect insolvency factors, such as demographic and socioeconomic factors as well as borrowing motives, on the ability of financial institutions clients' to fulfil undertaken financial obligations.

\section{Theoretical Aspects of Insolvency Interpretation}

The term personal „insolvency“ is described differently by various researchers. The concepts of solvency and its opposite, insolvency, can be simply defined as having either a positive or a negative net worth. In the equity sense, insolvency refers to the failure to submit timely debt repayment at the maturity (De Vaney, Lytton, 1995). This situation can result in an increase of liabilities and a reduction in the equity or assets held. In the bankruptcy sense, insolvency means that net assets at fair market value are less than liabilities, which can necessitate the liquidation of assets through a court-ordered bankruptcy process (De Vaney, Lytton, 1995).

Reifner et al. (2003) highlights the differences of term „insolvency“ in many countries. In Belgium, it is described as „incapability of paying debts“, in Great Britain: „as an inability of the debtor to pay the debt on which the petition is based, or in cases where the debt is not immediately payable, or the debtor appearing to have no reasonable prospect of being able to pay the debt“. In Austria, insolvency is described according to Austrian Bankruptcy Code: (1) Opening of the bankruptcy proceedings presupposes that the debtor is insolvent. (2) Insolvency has to be accepted in particular if the debtor stops his payments. (3) Insolvency does not presuppose that creditors crush. The circumstance in which the debtor satisfied demands of individual creditors totally or partly or still can satisfy, does not of itself justify the acceptance that he is solvent".

The formulations above are taken from legal documents, which regulate various processes of doubtful and risky loans. In addition, there are other streamlined formulations defining problematic financial situation of individuals according to scientific literature. For instance, „financial fragility“ (Jappelli et al., 2008), „financial vulnerability“ (Anderloni et al., 2012) and etc. These concepts also define that a person has financial problems and is unable to fulfil his obligations on time. 
In scientific literature, the term "insolvency" defines quite a wide spectrum of problems - from inability to pay loan instalments on time to personal bankruptcy. Considering all above mentioned, these conditions can be classified as follows (Table 1).

Table 1. Levels of financial problems in household

\begin{tabular}{|c|c|c|c|c|}
\hline $\begin{array}{l}\text { Level of the } \\
\text { problem }\end{array}$ & Definition & $\begin{array}{l}\text { Duration } \\
\text { of the } \\
\text { process }\end{array}$ & Possibilities & Scientific researches \\
\hline $\begin{array}{c}\text { I level: } \\
\text { Indebtedness }\end{array}$ & $\begin{array}{c}\text { Payment } \\
\text { delay for } \\
\text { more than } \\
1 \text { day }\end{array}$ & Short & $\begin{array}{l}\text { A person has } \\
\text { revenue/asset and } \\
\text { can pay his debt } \\
\text { as soon as } \\
\text { possible. The } \\
\text { debt occurred } \\
\text { because of } \\
\text { forgetfulness, } \\
\text { holidays or etc. }\end{array}$ & $\begin{array}{l}\text { Lusardi, Tufano, 2009; } \\
\text { Brown, Taylor, 2008; } \\
\text { Alfaro, Gallardo, 2012; } \\
\text { Kim et al., } 2014\end{array}$ \\
\hline $\begin{array}{l}\text { II level: } \\
\text { Insolvency }\end{array}$ & $\begin{array}{l}\text { Payment } \\
\text { delay for } \\
\text { more than } \\
\text { More than } \\
60 \text { days }\end{array}$ & Medium & $\begin{array}{l}\text { A person has no } \\
\text { revenue/asset and } \\
\text { can't pay his debt } \\
\text { promptly. The } \\
\text { debt occurred due } \\
\text { to job loss, } \\
\text { illnesses, serious } \\
\text { changes in family } \\
\text { structure and etc. }\end{array}$ & $\begin{array}{l}\text { Reifner et al., 2003; } \\
\text { Bishop, } 2013 .\end{array}$ \\
\hline $\begin{array}{c}\text { III level: } \\
\text { Bankruptcy }\end{array}$ & $\begin{array}{l}\text { Unable to } \\
\text { pay debts }\end{array}$ & Long & $\begin{array}{l}\text { There is no } \\
\text { possibility to pay } \\
\text { debts in several } \\
\text { years and even } \\
\text { higher income } \\
\text { level would not } \\
\text { help to solve the } \\
\text { problem. }\end{array}$ & $\begin{array}{l}\text { Walters, Smith, 2010; } \\
\text { Wyburn, } 2014\end{array}$ \\
\hline
\end{tabular}

Authors use the term "insolvency", which defines more than 60 days payment delay, but dissociate from bankruptcy in this research. The delayed loan itself is called unsecured or risky loan (based on the classification of the Bank of Lithuania) and the risk which financial institution faces due to unrecovered liability of insolvent debtor is going to be called insolvency risk in this article.

\section{Conceptual Framework of Insolvency Reasons}

Baek and Hong (2004) analysed insolvency problems in USA based on the life cycle hypothesis. They linked household debts with different human life cycles and changing needs. They highlight that it is difficult to finance new needs and harmonize them with current financial liabilities. 
Prinsloo (2002) relates personal debt level with the general country's economic situation in the Republic of South Africa. Meniago's et al. (2013) research also proves that macro-economic factors determine individual's financial situation and solvency. This also been confirmed by Meng et al. (2013) subsequent research. Results show that borrowing of Australian households is directly correlated with the growth of country's GDP. Interest rates, inflation and the level of unemployment are those macro-economic factors, which have impact on further financial liabilities fulfilment.

Ogawa and Wan (2007) relate the emergence of risky loans in Japan credit market with increased households' consumption expenses. The rapid growth of consumption, if it is funded not by own resources, but by loans from financial institutions, is indicated as the main reason for increasing number of people who face insolvency problems.

Jappelli et al. (2008) analysed Great Britain, German and USA households borrowing habits and indicate three main factors that may affect the indebtedness of individuals and their default rates. "(1) institutional features that shape the market's contracting environment, such as the degree of creditor rights protection, the effectiveness of their legal enforcement, and the information sharing arrangements among lenders; (2) demand-side factors, such as the age structure of the population and the degree of income inequality; (3) supply-side factors, such as the competitive structure of the credit market”.

Kirchler et al. (2008) relate insolvency with one's family status or it change, age, number of children in the family, etc. and call them "situational characteristics".

Worthington (2006) researched Australian credit market and linked the dynamics of risky loans portfolio with demographic and socioeconomic factors that influence client's financial behaviour. The direction of Wang et al. (2011) research is familiar - he analysed Chinese credit market and found that majorly the demographic and individual personal features such as responsibility, self-control and even self-respect determine whether an individual makes loan payments on time in the future. Furthermore, this group of scientists divide prior scientific researches into two parts:

1. Researches, where fulfilment of financial liabilities are analysed systematically taking into consideration economic, demographic and psychological factors.

2. Researches, where separate factors are analysed, e.g., fulfilment of financial liabilities are linked with credit risk management policy of financial institution or the client's personal finance management habits.

Anderloni et al. (2012) in their research about the growth of insolvent households in Italy take into account sociodemographic and economic factors and indicate four possible reasons for financial vulnerability: (1) 
presence of unplanned expenses, (2) high volume of current liabilities, (3) impulsive, uncontrolled consumption and its growth, (4) lack of financial knowledge. Furthermore, these researchers indicate credit market as the most vulnerable market due to these factors. Such loans are unsecured - without mortgage or sponsion; therefore, individuals repay such obligations at the latest.

Kim et al. (2014) noticed that in the last decade in Korea, households debts to financial institutions increased and could have been effected by three factors: (1) the increase of property prices, (2) beneficial and „relaxed“ borrowing conditions to get a loan, (3) decrease in growth of household income level.

Disney and Gathergood (2013) researched UK consumer credit market and concluded that individuals who have poor financial knowledge more often fail to fulfil financial obligations. Moreover, the credit expenditure often judged insufficiently as people fail to calculate the real borrowing price, which is influenced by rather high credit interest rates. These individuals also tend to understand borrowing deadlines as unlimited and ongoing, therefore often fail to make timely instalments, being unable to define the consequences.

Jurevičienè and Sukačevskytė (2013) similarly identified that failure to repay loans directly related with a lack of households' financial management skills. This means that households, that cannot or are unable to manage their finances adequately, are more likely to face insolvency problems.

There are many discussions, weather income level relates to ability to pay financial liabilities. For instance, Keese (2009) states that the volume of income does not have direct impact over client's solvency, unless a fluctuation of income is happening at the same time as another event, e.g., change in the number of family members, divorce, death of a spouse, etc. Later, Anderloni and Vandone (2010) have scientifically proven that presence of insolvency does not correlate with income level. Higher income does not guarantee financial liabilities payments in time. This also confirmed by Christelis et al. (2010) investigation, where it becomes apparent that even those households that are wealthy and have higher income than average level are still facing difficulties in fulfilling their obligations. Research results by Taujanskaitè and Milčius (2012) likewise confirm this. Households with higher income than country's average level more often face insufficient family budgets compared to those with average or below average income.

The findings of Alfaro and Gallardo (2012) research are completely different. After examining mortgage and consumer credit markets in Chile, they found that the only factor-influencing solvency of an individual is the level of income and demographic or various personal factors can only be 
identified as supplementary reasons. It was also stated that probability of insolvency decreases if there is an increase in households income. Giarda (2013), who was investigating reasons of insolvency of Italian households, also confirms this. It was decided that financial vulnerability decreases if there is personal income growth, however insolvency could increase in those areas, where unemployment growth exists. Taking everything into account, the results of investigations about correlation between income level and the presence of debts are very controversial.

After reviewing the scientific literature, it appears that individual's solvency can be affected by a number of factors: general economic situation in the country, unemployment rate, credit system features and others, e.g., financial knowledge and ability to manage financial resources, sense of duty and responsibility, ability to control ones consumption behaviour, etc.

With regard to above mentioned factors, relating it with household cash flows, the factors that influence the presence of insolvency were divided into two groups in this research (Figure 1):

- $\quad$ Direct factors that directly condition individual's cash flows (e.g., overall country's economic situation, employment rate, fluctuations of income level, etc.) and can be defined in quantitative financial/monetary terms;

- Indirect factors that indirectly influence personal cash flows (age, educations, marital status, financial literacy, etc.) and do not have defined quantitative financial/monetary form.

Based on this classification the research focuses on analysis of indirect factors that influence insolvency.

Figure 1. Factors determining insolvency due to their relation with individual's financial flows

\section{Direct Factors}

- Macroeconomic factors

(unemployment, inflation rate, GDP, demand/ supply features, etc.);

- Institutional features (credit policy of financial institution);

- Personal features (consumption expenditure, income level, changes in the number of dependents, life cycle stages, the number of liabilities and etc.).

\section{Indirect Factors}

- Demographic factors (age, gender, place of residence);

- Socioeconomic factors (marital status, education, financial literacy level);

- Psychological factors (borrowing motivation, sense of responsibility, self-esteem, self-control, etc.) 


\section{Correlation of Personal Insolvency with Indirect Determinants}

There are analysed indirect determinants influencing personal insolvency such as demographic (gender, age), socioeconomic (residence, family status) factors as well as aspects describing borrowing motivation (purpose of credit).

Data for the research was taken from one Lithuanian financial institution of consumer credit market (2012). Survey sample - 400 consumer credit contracts, bias - $5 \%$, probability - $95 \%{ }^{*} 110$. Data processed and correlation analysis made by using statistical program SPSS.

\section{Correlation of borrowing with demographic and socioeconomic factors}

In order to identify borrowing habits of individuals, first the impact of gender is analysed. Data obtained in survey were compared with data from Statistics Lithuania for 2012. Distribution of information is presented in Table 2.

Table 2. Distribution of sample and Statistics Lithuania data according to gender, percent (Source: Statistics Lithuania (2013) and sample data)

\begin{tabular}{|c|c|c|c|}
\hline Gender & Sample data & $\begin{array}{c}\text { Statistics Lithuania data } \\
\text { (population) }\end{array}$ & $\begin{array}{c}\text { Deviation from } \\
\text { statistics, \% }\end{array}$ \\
\hline Women & $52,0 \%$ & $55,4 \%$ & $-6,12 \%$ \\
\hline Men & $48,0 \%$ & $44,6 \%$ & $+7,62 \%$ \\
\hline
\end{tabular}

To ensure compatibility, the age group of 15-19 years was eliminated as credits can be granted only for people over 18 years in Lithuania and there are no borrowers beyond 20 age in the sample.

Computed positive difference (+7,62 \%) between sample and Statistics Lithuania data shows that men more frequently undertake financial liabilities. As the bias of population data is $\pm 5 \%$, it is presumable that there were from $45.6 \%$ to $50.4 \%$ men who used consumer credits in 2012.

Comparison of gender and credit amount data shows that the amount of consumer credits borrowed by women are less in average than by men, accordingly €2103.30 and €2393.28. Statistical significance of difference of these averages is verified using Student t-test average parity to prove or deny hypotheses:

$\mathbf{H}_{\mathbf{0}}$ : average amounts of consumer credits borrowed by men and women are equal $\left(\mu_{1}=\mu_{2}\right)$.

$\mathbf{H}_{\mathbf{1}}$ : average amounts of consumer credits borrowed by men and women are not equal $\left(\mu_{1} \neq \mu_{2}\right)$.

The level of significance is selected $\alpha=0,05$ and the analysis of Levine criterion is made.

\footnotetext{
${ }^{110}$ Computed with special program: http://www.factus.lt/main-calculator
} 
Levine test level of significance $p$-value is equal 0,027 (Table 3) and is less than chosen level of significance, consequently zero hypothesis is denied and alternative hypothesis is proven $\left(H_{1}\right.$ : men's and women's consumer credit distributions of dispersions statistically are not equal).

Table 3. The results of Student t-test criterion to verify parity of gender and average credit amount

\begin{tabular}{|c|c|c|c|c|c|c|c|c|c|}
\hline & $\begin{array}{r}\text { Levi } \\
\text { Test } \\
\text { Equal } \\
\text { Varia }\end{array}$ & $\begin{array}{l}\text { le's } \\
\text { for } \\
\text { ty of } \\
\text { ices } \\
\end{array}$ & \multicolumn{7}{|c|}{ t-test for Equality of Means } \\
\hline & \multirow[b]{2}{*}{$\mathrm{F}$} & \multirow[b]{2}{*}{ Sig. } & \multirow[b]{2}{*}{$\mathrm{T}$} & \multirow[b]{2}{*}{ df } & \multirow{2}{*}{$\begin{array}{l}\text { Sig. } \\
(2- \\
\text { tailed) }\end{array}$} & \multirow{2}{*}{$\begin{array}{c}\text { Mean } \\
\text { Difference }\end{array}$} & \multirow{2}{*}{$\begin{array}{c}\text { Std. Error } \\
\text { Difference }\end{array}$} & \multicolumn{2}{|c|}{$\begin{array}{l}\text { 95\% Confidence } \\
\text { Interval of the } \\
\text { Difference }\end{array}$} \\
\hline & & & & & & & & Lower & Upper \\
\hline $\begin{array}{c}\text { Equal } \\
\text { variances } \\
\text { assumed } \\
\text { Equal } \\
\text { variances not } \\
\text { assumed }\end{array}$ & 4,925 & 027 & $\begin{array}{c}- \\
1,884 \\
- \\
1,870\end{array}$ & \begin{tabular}{|c|}
398 \\
\\
372,133
\end{tabular} & ,040 & $\begin{array}{l}-1001,25918 \\
-1001,25918\end{array}$ & $\begin{array}{l}531,41085 \\
535,36547\end{array}$ & $\begin{array}{l}-2045,98227 \\
-2053,98001\end{array}$ & $\begin{array}{l}-43,46390 \\
-51,46164\end{array}$ \\
\hline
\end{tabular}

$P$-value is equal 0,042 (Table 3) and is less than chosen level of significance. Consequently zero hypothesis regarding parity of averages is denied and with $95 \%$ reliability could be stated that amount of consumer credits in average granted to women is statistically significantly less (from $€ 14.90$ to $€ 594.87)$ than to men.

Using the same calculation of average parity, it is proved with $95 \%$ of significance that average income of men and women statistically significantly differ - in average men earn from €28.80 to €139.20 more. Partly, it could explain why men receive bigger amounts of credits.

Survey of consumer credit demand and related risk is based on life cycle hypothesis, which states that overtaken risk and amount of liabilities relate on the age of individuals. Data of sample and Statistics Lithuania about distribution of population according age groups is presented in Table 4.

Table 4. Distribution of sample and Statistics Lithuania data on population according age groups, percent (Source: Statistics Lithuania (2013) and sample data)

\begin{tabular}{|c|c|c|c|}
\hline Age & Sample data & $\begin{array}{c}\text { Statistics Lithuania } \\
\text { data }\end{array}$ & $\begin{array}{c}\text { Deviation from } \\
\text { statistics, } \%\end{array}$ \\
\hline $\mathbf{2 0}-\mathbf{2 9}$ years & $21,3 \%$ & $17,3 \%$ & $+23,1 \%$ \\
\hline $\mathbf{3 0}-\mathbf{3 9}$ years & $32,8 \%$ & $16,0 \%$ & $+105 \%$ \\
\hline $\mathbf{4 0}-\mathbf{4 9}$ years & $26,8 \%$ & $18,6 \%$ & $+44,1 \%$ \\
\hline $\mathbf{5 0}-\mathbf{5 9}$ years & $13,5 \%$ & $18,0 \%$ & $-25 \%$ \\
\hline $\mathbf{6 0}-\mathbf{6 9}$ years & $5,0 \%$ & $13,1 \%$ & $-61,8 \%$ \\
\hline $\begin{array}{c}\mathbf{7 0} \text { years and } \\
\text { more }\end{array}$ & $0,8 \%$ & $17,0 \%$ & $-95,3 \%$ \\
\hline
\end{tabular}


Positive difference between data shows that demand of consumer credits is much higher among young people (20-49 years), while consumer credit demand among average age individuals (over 50 years) becomes negative. This trend relates to life cycle hypothesis - young people have more unfulfilled needs and often finance them via credits.

Comparing consumer credit customers according age and gender data, we see that an average age of women, who have a consumer credit, is a little bit above 42 years, while men - 37 years. Statistical significance of average is tested using Student t-test in order to approve or deny the following hypothesis:

$\mathbf{H}_{\mathbf{0}}$ : average age of men and women, who use consumer credits, is equal $\left(\mu_{1}=\mu_{2}\right)$.

$\mathbf{H}_{1}$ : average age of men and women, who use consumer credits, is not equal $\left(\mu_{1} \neq \mu_{2}\right)$.

To find out Student t statistics SPSS program is used.

After verification of hypothesis regarding customers' age it could be stated with $95 \%$ reliability that it statistically significantly differs. Levine $p$ value is higher than the level of significance (Table 5), id est 0,824 >0,05, thus dispersion of variables is equal, whereas p-value is equal 0.000 (Sig. 2tailed) and is less than chosen level of significance.

Table 5. The results of Student t-test to verify the parity of average gender and age

\begin{tabular}{|c|c|c|c|c|c|c|c|c|c|}
\hline & \multicolumn{2}{|c|}{\begin{tabular}{|l}
\multicolumn{2}{|l}{ Levine's } \\
Test for \\
Equality of \\
Variances \\
\end{tabular}} & \multicolumn{7}{|c|}{ t-test for Equality of Means } \\
\hline & \multirow[b]{2}{*}{$\mathrm{F}$} & \multirow[b]{2}{*}{ Sig. } & \multirow[b]{2}{*}{$\mathrm{t}$} & \multirow[b]{2}{*}{$\mathrm{df}$} & \multirow{2}{*}{$\begin{array}{l}\text { Sig. } \\
(2- \\
\text { tailed) }\end{array}$} & \multirow{2}{*}{$\begin{array}{l}\text { Mean } \\
\text { Difference }\end{array}$} & \multirow{2}{*}{$\begin{array}{l}\text { Std. Error } \\
\text { Difference }\end{array}$} & \multicolumn{2}{|c|}{$\begin{array}{l}95 \% \text { Confidence } \\
\text { Interval of the } \\
\text { Difference }\end{array}$} \\
\hline & & & & & & & & Lower & Upper \\
\hline $\begin{array}{l}\text { Equal variances } \\
\text { assumed } \\
\text { Equal variances } \\
\text { not assumed }\end{array}$ &, 049 & 824 & $\begin{array}{l}4,601 \\
4,603\end{array}$ & $\begin{array}{l}398 \\
396,018\end{array}$ & , ,000 & $\begin{array}{l}4,992 \\
4,992\end{array}$ & $\begin{array}{l}1,085 \\
1,084\end{array}$ & $\begin{array}{l}2,859 \\
2,860\end{array}$ & $\begin{array}{l}7,125 \\
7,124\end{array}$ \\
\hline
\end{tabular}

The obtained result means that zero hypothesis $\left(\mathrm{H}_{0}\right.$ : average age of men and women, who use consumer credits, is equal) is denied. In addition, it could be stated that in average the age of women who use consumer credits is higher than men from 2.859 to 7.123 years (95\% Confidence Interval of the Difference).

The evaluation of each gender in different age groups showed that the highest demand for credits is in the age group of 30-39 years and for both men and women almost the same. However, the decrease of consumer credit demand differs. For women it is in the age group of 50-59 years, for men in 
40-49 years. The elder are men, the demand of consumer credits decreases gradually, while the graph for women shows faster decrease of consumer credits demand in every decade (Figure 2).

Figure 2. Demand of consumer credits according different age groups and gender, percent

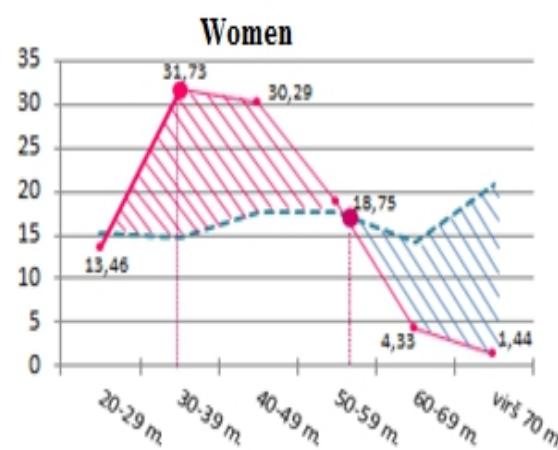

----Distribution of Lithuanian women population by age, $\%$

Distribution of women who use consumer credits by age, $\%$

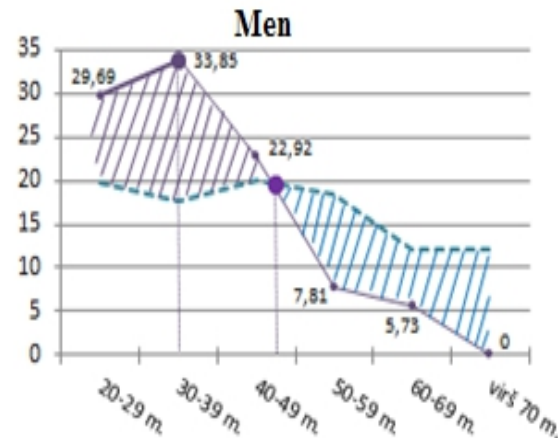

---- Distribution of Lithuanian men population by age, $\%$

Distribution of men who use consumer credits by age, $\%$

Analysing the impact of residence on the demand of credits, the percentage of sample and Statistics Lithuania data of population distribution according residence is computed (Table 6).

Table 6. Distribution of sample and Statistics Lithuania data of residence, percent

\begin{tabular}{|c|c|c|c|}
\hline $\begin{array}{c}\text { Place of } \\
\text { residence }\end{array}$ & Sample data & $\begin{array}{c}\text { Statistics Lithuania } \\
\text { data }\end{array}$ & $\begin{array}{c}\text { Deviation from } \\
\text { statistics, \% }\end{array}$ \\
\hline Urban & $51,2 \%$ & $41,0 \%$ & $+24,9 \%$ \\
\hline Other towns & $24,8 \%$ & $26,4 \%$ & $-6,06 \%$ \\
\hline Villages & $24,0 \%$ & $32,6 \%$ & $-26,4 \%$ \\
\hline
\end{tabular}

The computed positive difference $(+0,12 \%)$ shows that urban dwellers are more minded to undertake financial liabilities than others. The demand for consumer credits consisted of 48.64-53.76 \% of urban dwellers with $\pm 5 \%$ reliability in 2012. Partially, it could be related to the fact that majority of consumer credit companies are located in cities, so the supply and accessibility of these credits influences the demand.

\section{The study of demographic and socioeconomic factors impact on debt repayment}

Analysis of consumer credit agreements shows that nearly $40 \%$ of consumer credit clients (id est 159 from 400) are unable to repay credit on time and are treated as debtors (Figure 3). 
Figure 3. Distribution of credit customers according credit repayment on time, percent

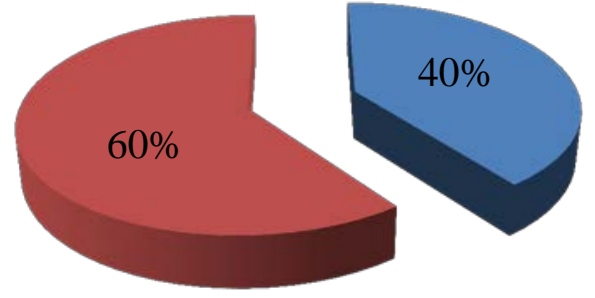

Customers that repay obligations on time

Customers that fail to repay obligations on time

Results show that insolvency risk exists, so the next step of investigation was to analyse other characteristics that could influence obligations repayment. Gender and repayment data were compared and it was found that $37.5 \%$ of women (78 from 208) and $42.2 \%$ of men (81 from 192) were unable to repay obligations on time and could be called debtors. These results could prove probable relationship between gender and default, as men in this case are a little bit more minded to delay payments.

The correlation of variables computed and tested using two hypothesis to estimate the impact of gender on repayment:

$\mathbf{H}_{\mathbf{0}}$ : correlation coefficient of gender and repayment is equal 0.

$\mathbf{H}_{\mathbf{1}}$ : correlation coefficient of gender and repayment is not equal 0.

Pearson correlation coefficient is used, level of significance was chosen $\alpha=0,05$.

Computed p-value is equal to 0.038 (Table 7) and is less than chosen level of significance, so hypothesis $H_{0}$ is denied and alternative hypothesis $H_{1}$ is proved $\left(H_{1}\right.$ : correlation coefficient of gender and obligations repayment is not equal 0). Consequently, it could be stated that gender influences repayment, id est variables are dependent.

Table 7. Pearson correlation coefficient testing relationship between gender and repayment

\begin{tabular}{|cc|c|c|}
\hline & & Gender & Repayment obligations \\
\hline Gender $\quad$ Pearson correlation & 1 &, $149^{*}$ \\
& p-value & &, 038 \\
& $\mathrm{~N}$ (number of observations) & 400 & 400 \\
\hline
\end{tabular}

*Correlation is significant with 0.05 level of significance (2-tailed)

The next step is to compare credit repayment according to the age groups. Life cycle hypothesis was taken into account (Figure 4). 
Figure 4. Percentage distribution of credit repayments and defaults according age groups

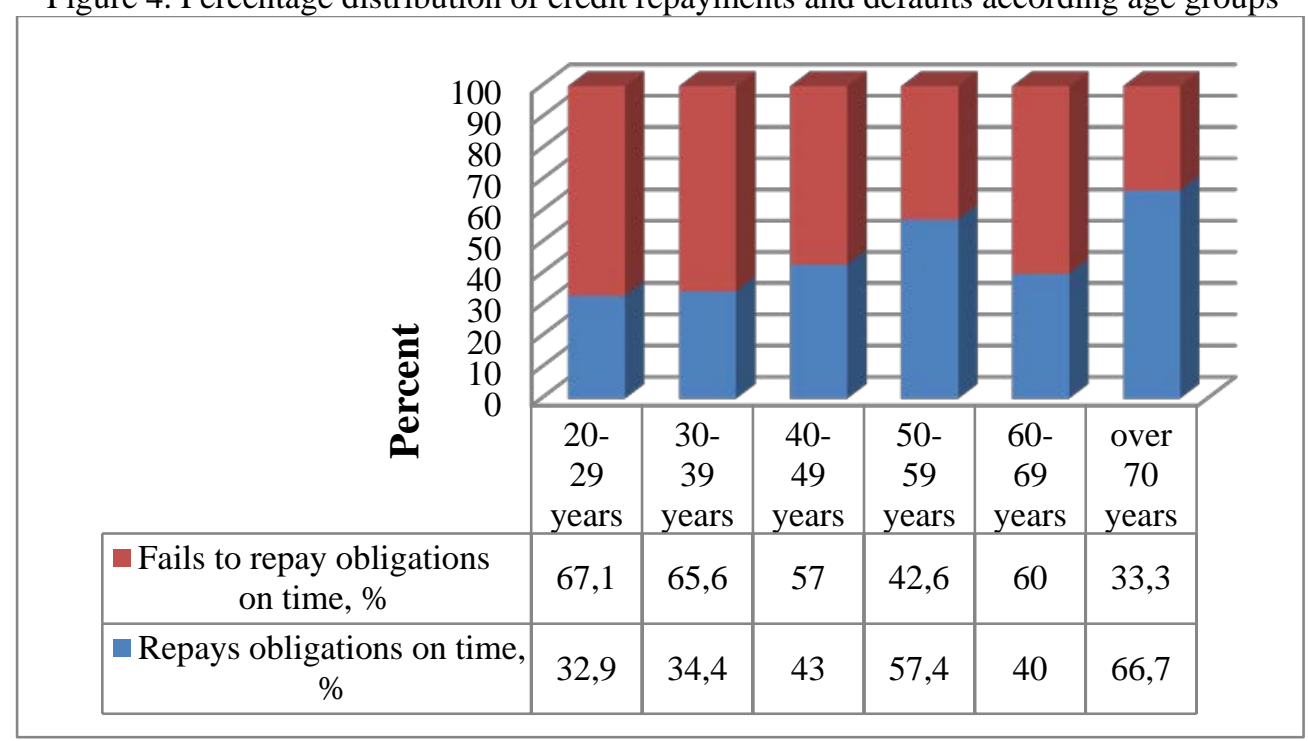

Data in Fig. 4 show that young people are more able to repay obligations, as $67.1 \%$ of customers from age group 20-29 years pay obligations on time. Applying Spearmen correlation coefficient, dependence of obligations repayment and gender was verified. Obtained level of significance is equal 0.007 and is less than chosen one, thus $\mathrm{H}_{0}$ is denied and alternative hypothesis $\mathrm{H}_{1}$ is proved. It could be stated that age has an impact on obligations repayment.

Using Spearman coefficient, the impact of such characteristics as marital status, residence were analysed (Table 8). The following hypothesis was settled:

$\mathbf{H}_{\mathbf{0}}$ : correlation coefficient of marital status or residence of an individual and obligations repayment is equal 0 .

$\mathbf{H}_{1}$ : correlation coefficient of marital status or residence of an individual and obligations repayment is not equal 0.

Table 8. The results of Pearson correlation coefficient to verify relationship between residence and marital status with repayment of obligations

\begin{tabular}{|c|c|c|}
\hline Repayment of obligations & Marital status & Residence \\
\hline Spearmen correlation coefficient &, $142^{* *}$ &, 040 \\
p-value &, 005 &, 430 \\
N (number of observations) & 400 & 400 \\
\hline
\end{tabular}

${ }^{* *}$ correlation is significant with 0.01 level of significance (2-tailed)

Analysis of impact of residence show that calculated level of significance is more than chosen level $\alpha$, i. e. $0.430>0.05$, thus zero hypothesis is proved $\left(H_{0}\right.$ : correlation coefficient is equal 0$)$ and correlation is 
insignificant. Thus, we can state that residence of an individual have no impact on financial liabilities fulfilment.

Investigation of impact of marital status on individuals' solvency (Table 8) shows that computed meaning is less than chosen level of significance $(0,005<0,05)$. This means that zero hypothesis has to be rejected and alternative hypothesis is proved $\left(H_{1}\right.$ : correlation coefficient is not equal 0$)$.

Thus, correlation is significant and the marital status of an individual has an impact on obligations fulfilment. Distribution of individual's marital status and financial liabilities fulfilment is shown in Figure 5.

Figure 5. Distribution of marital status and financial liabilities fulfilment, percent

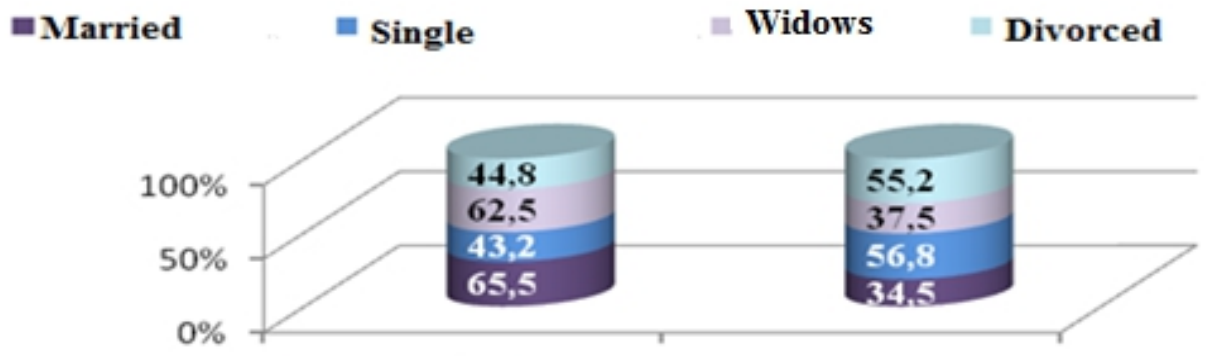

Fulfill financial liabilities on time, \%
Fail to fulfill financial

liabilities on time, \%

Results in Figure 5 show that the most accurate/responsible in fulfilling their obligations are married persons or widows (accordingly 65.53 and 62.5 percent), while single and divorced individuals more often fail to repaye their obligations.

\section{Insolvency relationship with borrowing motives}

The last group of psychological factors could be analysed only using questionnaire of the borrowers. Unfortunately, it was impossible to make this with specified clients, so the last group of factors is presented in part. Identified borrowing motives from previous research of one of the author (Jurevičienè, Sukačevskyte, 2014) used and compared with the results of data sample of the same financial institution.

Expert evaluation analysis was done to identify various borrowing motives in consumer credit market (Jurevičienè, Sukačevskytè, 2014). Analysis contained both - performing and non-performing loans. Experts were asked to identify main motives for getting a loan. Figure 6 illustrates their ranks. Specialists noticed that borrowing from consumer credit providers mostly occurs in order to pay expensive purchases, to refinance current debts or to finance daily consumption needs. 
Figure 6. Relationship between borrowing motivation and risky loans, EUR

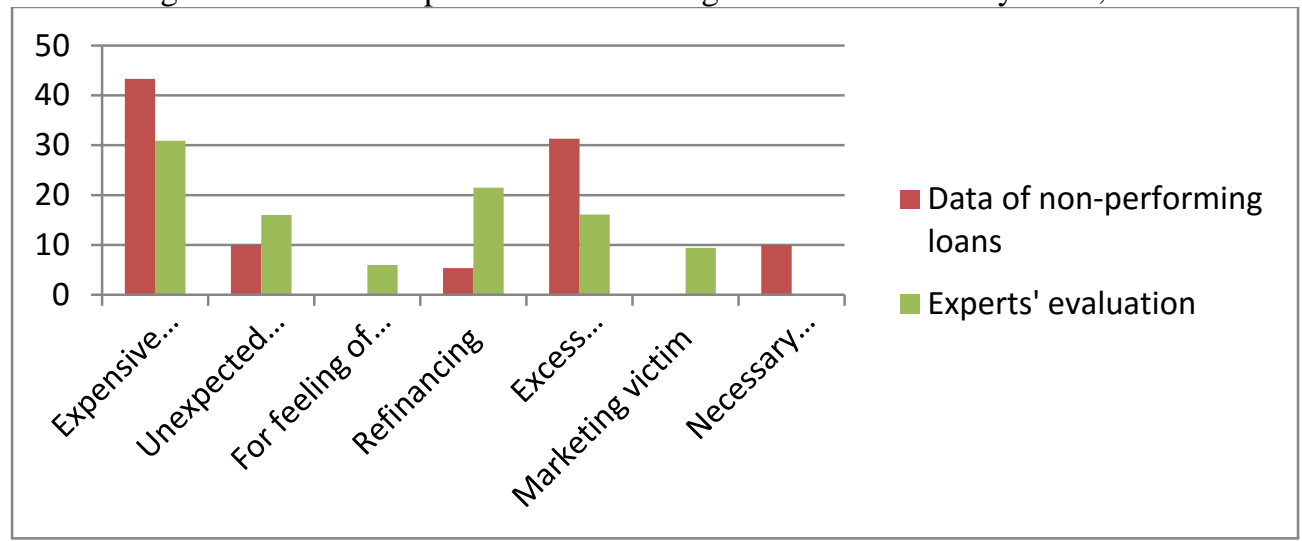

Comparing results of experts evaluation (2014) with the same sample of non-performing loans portfolio, it was analysed which loans fall into this segment (Figure 6).

According to the market data, contracts signed for purchasing expensive items or related to overconsumption, e.g. for travelling or entertainment, more often fall into the risky loans group than others. Furthermore, those clients who take loans for financing unexpected financial occurrences or for refinancing current liabilities are much more reliable clients than those who do not have financial difficulties. Consequently, if a loan is taken responsibly and for a very particular purpose, it is more likely that such individual will perceive this loan more responsibly than one who borrowed just for consumption. Considering the made research it should be stated that person's solvency depends more on motivation than on previously analysed indirect factors. The purpose of the credit is one of the most important factors, which can determine individual's solvency in the future.

\section{Conclusion}

A variety of factors influences the credit risk and solvency of individuals. To summarize and evaluate the impact of factors on risky loans it is suggested to classify them into two groups based on their impact on household's financial flows: (1) Direct, which have direct impact on households financial flows and can be expressed in quantitative/monetary form, e.g., change of income level. (2) Indirect, which affect individuals financial flows indirectly and cannot be defined in a monetary form, e.g. gender, age, residence, purpose of the loan etc.

After investigating data of 400 consumer credits, correlation between propensity to use credits and demographic, socioeconomic factors such as age, gender, residence, etc., the following findings were identified: 
- $\quad$ Men are more likely to undertake consumer credits than women, but women borrow smaller amounts than men;

- $\quad$ An average age of a woman - consumer credits borrower is 42 years, of a man - 37 years old;

- $\quad$ Consumer credit demand is much higher among younger people (2049 years age category), compared to elder (over 50);

- $\quad$ Residents of large cities are more likely to use consumer credits compared to ones who live in towns and villages.

Investigation of the impact of gender, age, marital status, etc. on individual's solvency in consumer credit market shows that:

- $\quad$ There are $12 \%$ more men debtors than women;

- $\quad$ Married or widowed people are more responsible fulfilling liabilities on time compared to divorced or single ones;

- It was identified that place of residence has no impact on solvency. Research findings did not show any tendencies, allowing forecasting better debts repayment relating to the place of residence.

Investigation has proved that the most influencing indirect factor is borrowing motivation. It was indicated that the majority of risky loans were granted for expensive purchases or excessive consumption financing, while those for refinancing of current debts were repaid more responsibly. As a result, borrowing motives in particular are the main reason for failing to fulfil consumer credit contracts.

It could be concluded that motivation of borrowing is influenced by excessive consumption and its supportive environment. Besides competition among consumer creditors, level of individual's financial literacy, ability to manage ones needs and adequately understand the terms and conditions of borrowing have an impact on insolvency in consumer credit market either.

\section{References:}

Alfaro, R. \& Gallardo, N. (2012). The Determinants of Household Debt Default. Revista de Análisis Económico, 27(1), 55-70.

Anderloni, L.; Bacchiocchi, E. \& Vandone, D. (2012). Household financial vulnerability: An empirical analysis. Research in Economics, 66, 284-296.

Anderloni, L. \& Vandone, D. (2010). Risk of overindebtedness and behavioural factors. In: Lucarelli, C., Brighetti, G. (Eds.), Risk Tolerance in Financial Decision.

Brown, S. \& Taylor, K. (2008). Household debt and financial assets: evidence from Germany, Great Britain and the USA. Journal of the Royal Statistical Society, 17, 615-643. 
Christelis, D., Jappelli, T., Paccagnella, O., \& Weber, G. (2010). Income, wealth and financial fragility in Europe. Journal of European Social Policy, 19(4), 359-376.

Baek, E. \& Hong, G. S. (2004). Effects of Family Life-Cycle Stages on Consumer Debts. Journal of Family and Economic Issues, 25(3), 359-385.

Bank of Lithuania (2015). The Review of Commercial Banks Performance in Lithuania. Retrieved from: https://www.lb.lt/n25606/2015_06_12_banku_veiklos_apzvalga_2015q1.pdf Bishop, P. (2013). The Spatial Distribution of Personal Insolvencies in England and Wales, 2000-2007. Regional Studies, 47(3), 419-432. http://dx.doi.org/10.1080/00343404.2011.581653.

De Vaney, S. A. \& Lytton, R. H. (1995). Household Insolvency: A Review of Household Debt Repayment, Delinquency and Bankruptcy. Financial Services Review, 4(2): 137-156.

Disney, R. \& Gathergood J. (2013). Financial literacy and consumer credit portfolios. Journal of Banking \& Finance, 37, 2246-2254.

Giarda, E. (2013). Persistency of financial distress amongst Italian households: Evidence from dynamic models for binary panel data. Journal of Banking \& Finance, 37, 3425-3434.

International Monetary Fund. (2013). Technical note on the financial situation of Italian households and non-financial corporations and risks to the banking system. Retrieved from Internet: www.imf.org/external/pubs/ft/scr/2013/cr13348.pdf.

Jappelli, T.; Pagano, M. \& Di Maggio, M. (2008). Households’ Indebtedness and Financial Fragility. 9th Jacques Polak Annual Research Conference, Washington, DC-November 13-14, 2008.

Jurevičienè, D. \& Sukačevskytè, V. (2013). Factors of households'default. Journal Acta Oeconomica Universitatis Selye: Vedecký recenzovaný časopis, 2(1), 131-143.

Jurevičienè, D. \& Sukačevskytè, V. (2014). Factors affecting personal insolvency. KSI Transactions on Knowledge Society, 7(3), 5-11.

Keese, M. (2009). Triggers and Determinants of Severe Household Indebtedness in Germany. Ruhr economic papers, No. 150.

Kirchler, E.; Hoelzl, E. \& Kamleitner, B. (2008). Spending and credit use in the private household. The Journal of Socio-Economics, 37, 519-532.

Lusardi, A. (2006) Comment on: “A portfolio view of consumer credit". Journal of Monetary Economics, 53, 85-88.

Lusardi, A. \& Tufano, P. (2009). Debt Literacy, Financial Experience and Overindebtedness. NBER Working Paper, 14808.

Kamleitner, B. \& Kirchler, E. (2007). Consumer credit use: a process model and literature review. Revue européenne de psychologie appliquée, 57, 267283. 
Kim, H. J.; Lee, D.; Son, J. C. \& Son, M. K. (2014). Household indebtedness in Korea: Its causes and sustainability. Japan and the World Economy, 29, 59-76.

Meniago, C.; Petersen, J. M.; Petersena, M. A. \& Mongale, I. P. (2013). What causes household debt to increase in South Africa? Economic Modelling, 33, 482-492.

Meng, X.; Hoang, N. T. \& Siriwardana, M. (2013). The determinants of Australian household debt: A macro level study. Journal of Asian Economics, 29, 80-90.

Ogawa, K. \& Wan, J. (2007). Household debt and consumption: A quantitative analysis based on household micro data for Japan. Journal of Housing Economics, 16, 127-142.

Pahl, J. (2008). Family finances, individualisation, spending patterns and access to credit. The Journal of Socio-Economics, 37, 577-591.

Prinsloo, J. W. (2002). Household debt, wealth and saving. Quarterly Bulletin, December 2002, SA RESERVE BANK.

Reifner, U.; Kiesilainen, J.; Huls, N. \& Springeneer, H. (2003). Consumer Overindebtedness and Consumer Law in the European Union. Institute for Financial Services. Retrieved from: http://www.ecri.eu/new/system/files/26+consumer_overindebtedness_consu mer_law_eu.pdf.

Statistics Lithuania. (2013). Residents and Social Statistics. Retrieved from: http://db1.stat.gov.lt/statbank/SelectTable/Omrade0.asp?SubjectCode=S3\&S howNews $=$ OFF\&PLanguage $=0$.

Taujanskaitè, K. \& Milčius, E. (2012). Impact of financial crisis on Lithuaniain households" ability to manage budgets. 7th International Scientific Conference “Business and Management 2012” May 10-11, 2012, Vilnius, Lithuania. doi:10.3846/bm.2012.031.

Walters, A. \& Smith, A. (2010). Bankruptcy Tourism' under the EC Regulation on Insolvency Proceedings: A View from England and Wales. International Insolvency Review, 19(3), 181-208.

Wang, L.; Lu, W. \& Malhotra, N. K. (2011). Demographic, attitude, personality and credit card features correlated with credit card debt: A view from China. Journal of Economic Psychology, 32, 179-193.

Worthington, A. C. (2006). Debt as a source of financial stress in Australian households. International Journal of Consumer Studies, 30(1), 2-15.

Wyburn, M. (2014). Debt Agreements for Consumers under Bankruptcy Law in Australia and Developing International Principles and Standards for Personal Insolvency. International Insolvency Review, 23, 101-121. 